\title{
Accommodative Study of Public Space for Marginalized People
}

\author{
Wakhidah Kurniawati \\ Faculty of Engineering, \\ Diponegoro University, Semarang \\ w4t1ek@yahoo.com
}

\begin{abstract}
A good public space must be accommodative for everyone included the marginal, the forgotten, the silent (Badshah, 1996), and an undesirable people. "Cities for the Citizen '(Douglas \& Friedmann, 1998) serves a slogan. Accommodative public space for marginal people and marginal activities can be created when physical aspects of space can accommodate the space needs of the Forgotten (Badshah, 1996). Thus, the society will be educated to learn and share, to respect the rights of other users in the city, and consequently the physical quality of the visual city will be better because there are no annexation of space and overlapping activities.
\end{abstract}

Keywords: accommodative public space, marginal people, marginal activities

eISSN 2514-751X @ C 2018. The Authors. Published for AMER ABRA cE-Bs by e-International Publishing House, Ltd., UK. This is an open access article under the CC BY-NC-ND license (http://creativecommons.org/licenses/bync-nd/4.0/). Peer-review under responsibility of AMER (Association of Malaysian Environment-Behaviour Researchers), ABRA (Association of Behavioural Researchers on Asians) and cE-Bs (Centre for EnvironmentBehaviour Studies), Faculty of Architecture, Planning \& Surveying, Universiti Teknologi MARA, Malaysia.

DOI: https://doi.org/10.21834/aje-bs.v3i6.230 


\subsection{Introduction}

Public space (Wikipedia, cited at 2011) means a social space as a town square that is open and accessible to all, regardless of gender, race, ethnicity, and age or socio economic level. There is no fee and no discriminative entrants on background in public space. Actually, public space has a function as an agglomeration of people, objects and events (Madanipour, 1996:3). Public spaces have at least three basic things those are responsive, democratic and meaningful (Carr, 1992:19). Responsive means that public space should be able to accommodate a variety of activities, interests and desires of the user. Democratic means of public space should be usable by the general public from various social backgrounds, economic and cultural as well as accessible to a variety of human physical condition without any discrimination. Public space must ensure that the various activities and other interests do not interfere with each other. Meaningful means that public space must have a linkage between human, space and the world at large as well as with social context. Public spaces can give meaning or significance to local communities by individuals or groups.

\subsection{Literature Review}

\subsection{History and the role of public space}

Based on the history of public space in Greek and Rome Period, there was a great role of public space to educate the citizen to share the space for another people. In the Greek period, there was an agora where accommodate people to replace themselves in this space. They can do social activities, trade, and express their opinion to others. In this time, we ever heard the famous Socrates, one the product of the freedom of public space (Gallion, 1986). Then, in the Rome Period, there was a forum as a great public space. Forum was the center of Roman public life: the site of triumphal processions and elections, venue for public speeches, criminal trials, and gladiatorial matches, and nucleus of commercial affairs. Here statues and monuments commemorated the city's great men. The teeming heart of ancient Rome, it has been called the most celebrated meeting place in the world, and in all history (Grant, Michael (1970), The Roman Forum, London: Weidenfeld and Nicholson; cited at Wikipedia March 2011).

\subsection{The typical and the development of public space}

Tshumi on Madanipour (1996:7) remind us about the important to defining space. One of them is 'to make space distinct'. Public space sometimes is understood as a gathering space. According to Wikipedia definitions (cited at March 2011), we know that most street, including the pavement are considered public space, as are town squares or parks. Public space is commonly shared and created for open usage throughout the community. Everyone has a right to access and use public space.

The type of public space can be divided as square (nodal) and linier (like street and 
pavement). Public space has a certain hierarchy in city's system. Like town square (alunalun in Indonesia) for all citizen in the city, park for sub central area, playground for neighborhood.

The development of public space is influenced by the contemporary issue, like: equity in public space (Carr 1992, Madanipour 1996, Badshah 1996, Cooper and Fancis 1997), safety in public space with Defensible Space by Newman (1972) and Crime Prevention Through Environmental Design (CPTED) by Jeffery 1971 at Matthew 1996, Convivial City, Human Aspect in Urban Form (Rapoport, 1977), and another issues. Day by day, the planner and citizen try to share those ideas in public spaces.

\subsection{Marginalized people as an important part of public space users}

In addition to these three basic things, user of public space has the rights in its use, among others: the right to access, performs activities, and makes confession and to make changes (Carr, 1992). Freedom to access a public space, this right is the most basic things. Freedom to do activities that is the freedom to use and perform the desired activity but with an awareness that public space is a space for the common good and lawful regulations. The freedom to make changes such as the right to make some changes either temporarily or permanently, because change is an important dimension in the success of a public space, for example, people can bring decorations, picnic tables or badminton net to change the appearance and function of public space.

Sometime, our public space can't accommodate these communities' rights. Then, the communities become be marginalized in public space. Sometime, they are become the forgotten, the silent, and undesirable people. To be marginal is to be marginalized. Taken broadly, the term "marginalization" evokes a dynamic between two social analytic categories: the "center" (or mainstream), and an area called the "margins." The center is normally associated with dominance, privilege, and power; the margins, with relative powerlessness. To be marginalized is to be placed in the margins, and thus excluded from the privilegeand power found at the center. Marginalization is often based on such notions as gender, culture, language, race, sexual orientation, religion, political affiliation, socioeconomic position or class, and geographic location. Depending on the context and level of analysis, individuals, groups, organizations, communities, and even entire geopolitical systems can be seen as marginalized (http://www.answers.com/ topic/marginal-people\#ixzz1HDDMOJms cited at March 2011).

Based on Badshah (1996: 22-27), we can divide the marginal community as:

Table 1: The Marginal Communities

\begin{tabular}{|l|l|}
\hline The Marginal & Women; informal sector \\
\hline The Forgotten & The elderly and disabled \\
\hline The Silent & Children \\
\hline The Undesirable people & The homeless and street people \\
\hline
\end{tabular}

(Source: Badshah, 1996) 


\subsection{Methodology}

So, how to create accommodative public space for marginal people and marginal uses? Based on qualitative descriptive method, we will formulate the ideal public space for marginal people. Then the result shows that we need the certainty space for everyone.

\subsection{Results and Discussions}

According to a lot of bad and best practice all the world, we can notice a small note:

Table 2 : The Marginal Communities Problems

\begin{tabular}{|c|c|c|c|}
\hline Locus & $\begin{array}{l}\text { Empirical } \\
\text { Phenomena }\end{array}$ & What happened? & $\begin{array}{l}\text { What should we } \\
\text { do? }\end{array}$ \\
\hline $\begin{array}{l}\text { Indonesia and } \\
\text { developing } \\
\text { countries }\end{array}$ & $\begin{array}{l}\text { Street vendor; } \\
\text { informal sector } \\
\text { at public space. }\end{array}$ & $\begin{array}{l}\text { Out of Place, dirt the visual, violating } \\
\text { public order [Yatmo, 2008] } \\
\text { Overlapping activities between legal } \\
\text { and illegal sector (occupied public } \\
\text { space). } \\
\text { Marginal uses of space. }\end{array}$ & $\begin{array}{l}\text { Law enforcement } \\
\text { to enabling } \\
\text { informal uses in } \\
\text { public space } \\
\text { Create the } \\
\text { certainty space for } \\
\text { informal sector. } \\
\text { Legalize the illegal } \\
\text { sector with license } \\
\text { (Singapore, } \\
\text { Hongkong) } \\
\text { Create the } \\
\text { informal sector as } \\
\text { an } \\
\text { destination exotic } \\
\text { (Malioboro, } \\
\text { Yogyakarta and } \\
\text { Thailand) }\end{array}$ \\
\hline
\end{tabular}




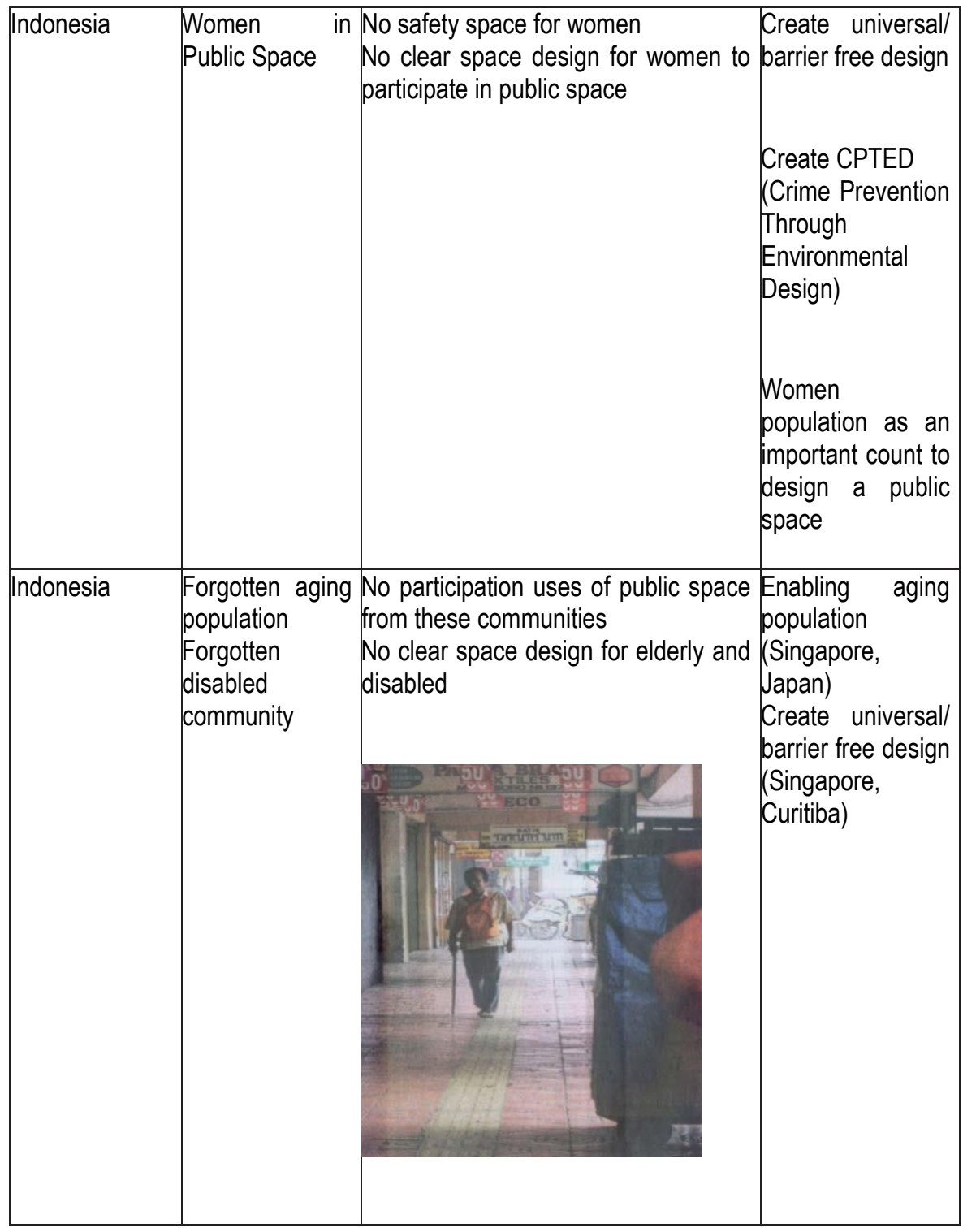




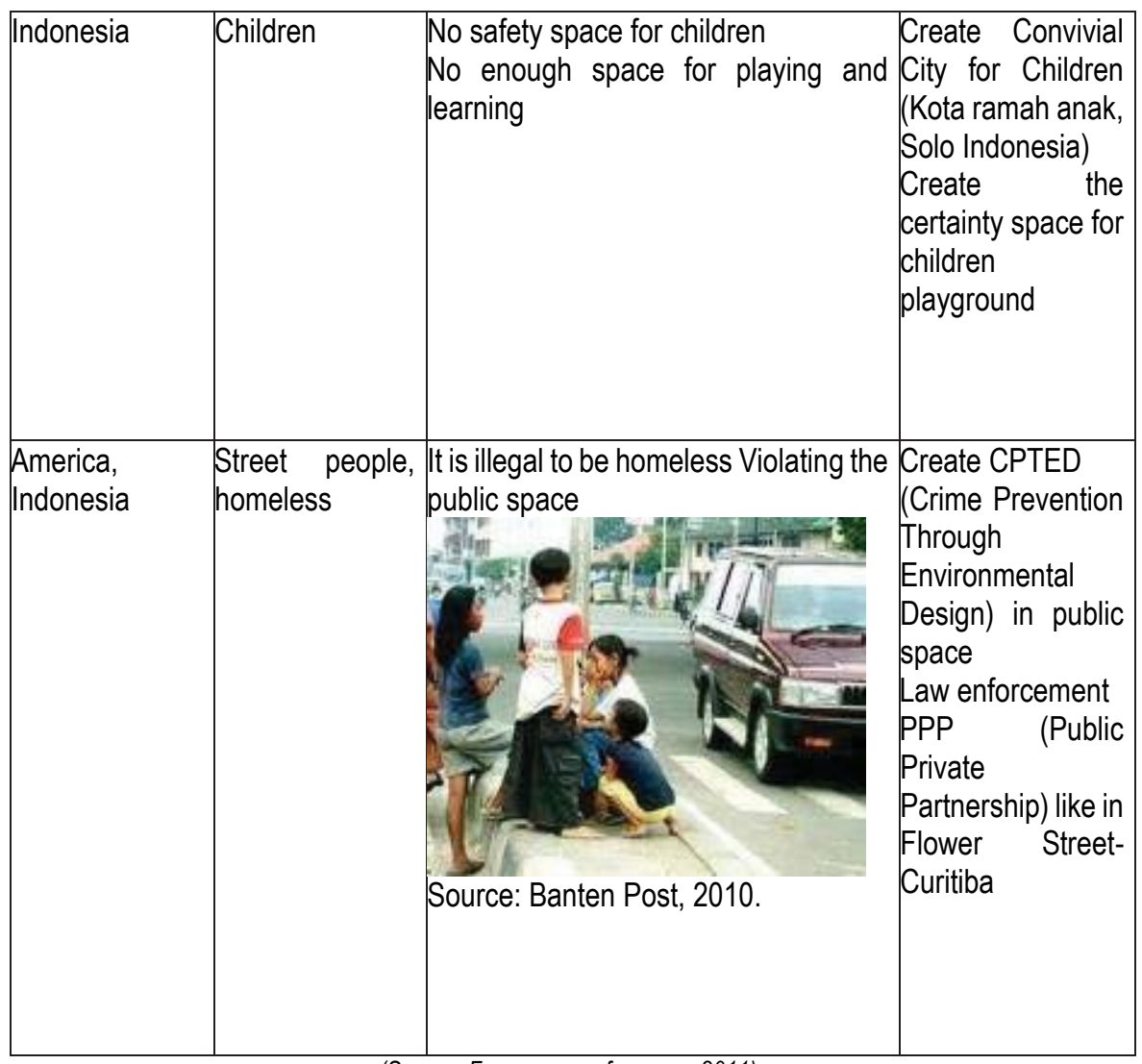

(Source: From many references, 2011)

And, then from the table above we will conclude the ideal and accommodative public space for marginal people. Based on http://www. pps.org/articles/grplacefeat/ (cited at March 2011), Project for Public Space (PPS) has found that successful public spaces have four key qualities: they are accessible; people are engaged in activities there; the space is comfortable and has a good image; and finally, it is a sociable place: one where people meet each other and take people when they come to visit. PPS developed The Place Diagram as a tool to help people in judging any place, good or bad: 


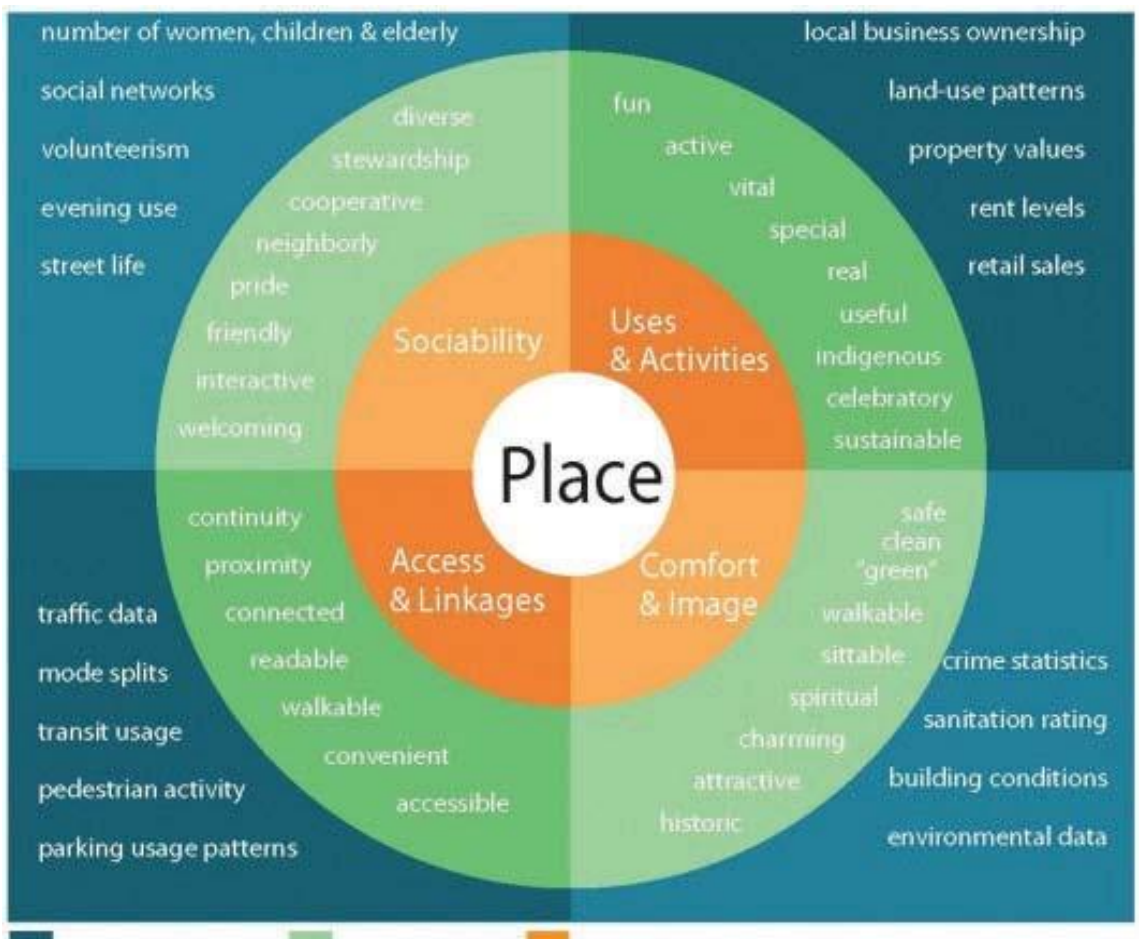

MEASUREMENTS

INTANGIBLES

Figure 1: The Place Diagram

(Source :www.pps.org)

\subsection{Conclusion}

Now, according to Sandercock at Douglas, 1998, we must underline and hear the borderless voices (the marginal people). Then, we need a written proof upon the space for legality urban plan for the marginalized community to resolve the issues. When the physical aspects of space can accommodate the space needs of the Forgotten (Badshah, 1996), accommodative public space will be created. Thus, as society will be educated to learn and share, to respect the rights of other users in the city, and consequently the physical quality of the visual city will be better because there are no annexation of space and overlapping activities. So, we can create the public space for public use (adapted from Moudon, 1987). 


\section{References}

Badshah, Akhtar A. (1996). Our Urban Future, New Paradigms for Equity and Sustainability. London \& New Jersey: Zed Books Ltd

Carr, Stephen et al. (1992). Public Space. New York : Van Nostrand Reinhold Company.

Cooper and Francis. (1997). People Places. New York : Van Nostrand Reinhold Company.

Dictionary.com, Random House. 2011 http://www.answers.com/topic/ marginal-people\#ixzz1HDDMOJms www.cpted.com.au. http://www.pps.org/articles/grplacefeat/www.romanforum.org http://www.wikipedia.org.

Douglass, Mike and Friedmann, John. (1998). Cities For Citizen. Planning and The Rise of Civil Society in A Global Age. England: John Wiley and Sons.

Firdaus, Ginanjar. (2007). Peluang Pengembangan Public Skatepark di Ruang Terbuka Publik Pusat Kota Semarang. Tugas Akhir tidak diterbitkan, Perencanaan Wilayah dan Kota, Fakultas Teknik Universitas Diponegoro, Semarang.

Gallion, Arthur B and Eisner, Simon. (1986). The Urban Pattern: City Planning and Design. Van Nostrand Reinhold Company.

Hall, Peter and Pfeifer, Ulrich. (2000). Urban Future 21, A Global Agenda for Twenty-First Century Cities. The Federal Ministry of Transport, Building and Housing of the Republic of Germany. NY: E \& FN Spon.

Harvey, David. (1973). Social Justice and the City. London: Erdward Arnold. Madanipour, Ali. (1996). Design of Urban Space; an Inquiry into a Socio-spatial Process. Chichester, England: John Wiley \& Sons.

Moudon, Anne Vernez. (1987). Public StreetforPublic Use. New York: Columbia University Press.

Newman, Oscar.(1972). Defensible Space. New York: Macmillan.

Newman, Oscar. (1996). Creating Defensible Space. U.S.: Department of Housing and Urban Development Office of Policy Development and Research.

Oxford Learner's Pocket Dictionary.1983.

Robinson, Matthew.(1996). The Theoretical Development Of 'CPTED': 25 Years Of Responses To C. Ray Jeffery .

Setiawan, Bobi. (2004). "Ruang Publik Dan Modal Sosial : Privatisasi Ruang Di Kampung." InfoURDI, Vol. 17, AprilJuni.

Syamsura, Ary. (2004). Ruang Publik Bagi Publik dalam InfoURDI Vol. 17, April-Juni 2004.

Yatmo, Yandi Andri. (2008). Street Vendors as 'Out of Place' Urban Elements. Journal ofUrban Design, Vol. 13. No. 3,387-402, October2008. Routledge, Taylor and Francis Ltd. 